\title{
PENGARUH PROPILEN GLIKOL TERHADAP LAJU DIFUSI KRIM NATRIUM DIKLOFENAK DENGAN BASIS HIDROFOBIK SECARA INVITRO
}

\author{
Angga Cipta $\mathbf{N}^{1)}$, Boesro Soebagio ${ }^{2)}$, dan Sriwidodo ${ }^{2)}$ \\ Kelompok Bidang Ilmu Farmasetika, Fakultas Farmasi, Universitas Mulawarman, Samarinda \\ e-mail : anggaciptanarsa@gmail.com ${ }^{\text {l) }}$ \\ Fakultas Farmasi, Universitas Padjadjaran, Bandung ${ }^{2)}$
}

\begin{abstract}
The research on effect of propylene glycol in diffusion of cream diclofenac sodium from hydrophobic base with in-vitro. The research has been used for concentrations propylene glycol (0, 3, 5, and 7\%). The stability test included organoleptic, $\mathrm{pH}$, viscosity, consistency, flow type for 56 days of storge, and diffusion test used diffusion franz cell and membrane spangler. The result showed that formula diclofenac sodium cream contained propylene glycol $7 \%$ was the one best in diffusion of $0.0203 \mathrm{ppm} / \mathrm{menit}$.
\end{abstract}

Key words : Propylene glycol, diffusion, hydrophobic base

\begin{abstract}
ABSTRAK
Telah dilakukan penelitian mengenai pengaruh propilen glikol terhadap laju difusi krim natrium diklofenak basis hidrofobik secara invitro. Dalam penelitian ini dibuat formula dengan variasi konsentrasi propilen glikol yaitu $0,3,5$, dan $7 \%$. Pengujian stabilitas fisik sediaan krim meliputi organoleptis, $\mathrm{pH}$, viskositas, konsistensi, dan uji sifat aliran selama 56 hari penyimpanan, serta uji difusi menggunakan alat difusi Franz dan membran spangler. Dari hasil penelitian ini didapat bahwa formula krim natrium diklofenak yang mengandung propilen glikol $7 \%$ memiliki laju difusi paling baik yaitu $0,0203 \mathrm{ppm} / \mathrm{menit}$.
\end{abstract}

Kata kunci : Propilen glikol, laju difusi, basis hidrofobik

\section{PENDAHULUAN}

Sediaan transdermal merupakan salah satu cara penghantaran obat secara topikal yang dapat memberikan efek sistemik serta kemudahan pemakaian oleh konsumen. Pemberian sediaan transdermal menghasilkan pelepasan obat ke sistem tubuh melalui kulit. Rute pemberiaan ini dapat melepaskan obat dalam beberapa jam tanpa menimbulkan efek saluran cerna yang tidak menyenangkan (Shargel, 1988).

Natrium diklofenak merupakan salah satu obat antiinflamasi nonsteroid (AINS) yang potensial berefek analgesik. Natrium diklofenak sering digunakan untuk mengobati rheumatoid arthritis karena mempunyai efek yang lebih baik pada serangan akut maupun pada pengobatan jangka panjang. Efek terapi dan efek samping yang sering ditimbulkan dari obat ini berdasarkan dari penghambatan bioseintesis prostaglandin (PG), yaitu dengan menghambat kerja dari enzim siklooksigenase yang berperan dalam pembentukan prostaglandin. Natrium diklofenak diabsorpsi dengan cepat pada pemberian peroral, serta memiliki waktu paruh singkat yaitu 1-3 jam. Efek samping yang ditimbulkan yaitu mual, gastritis, dan sakit kepala sehingga penggunaan obat ini 
harus dilakukan dengan hati-hati pada penderita tukak lambung (Syarif dkk, 1998).

Krim adalah sediaan setengah padat berupa emulsi, mengandung satu atau lebih bahan obat terlarut atau terdispersi dalam bahan dasar yang sesuai dan dimaksudkan untuk pemakaian luar. Krim lebih disukai dibandingkan dengan salep karena daya tarik estetiknya, mudah menyebar dengan rata, mudah diserap kedalam kulit jika digosokkan, mampu melekat pada permukaan kulit dalam waktu yang cukup lama, dan mudah dicuci (Lachman, 1994).

Zat tambahan pada sediaan topikal salah satunya yaitu zat peningkat penetrasi. Zat peningkat penetrasi merupakan zat tambahan yang dimaksudkan untuk meningkatkan jumlah zat yang terpenetrasi agar dapat digunakan untuk tujuan pengobatan sistemik melalui kulit. Adapun syarat-syarat zat peningkat penetrasi antara lain yaitu tidak mempunyai efek farmakologi, tidak meyebabkan iritasi alergi atau toksik, dapat bercampur secara fisika dan kimia dengan banyak zat, dan dapat dibuat dalam berbagai sediaan (Agoes, 1993).

Propilen glikol dalam sediaan farmasi berfungsi sebagai humektan, pelarut, pelicin, dan sebagai penghambat fermentasi dan pertumbuhan jamur, desinfektan, dan untuk meningkatkan kelarutan (Weller, 1994). Selain itu juga penambahan propilen glikol pada sediaan topikal juga dapat meningkatkan laju difusi (Agoes dkk, 1983).

Untuk mengetahui laju dan pengaruh zat peningkat penetrasi dilakukan pengujian pelepasan zat aktif secara in vitro dari sediaan semi solid dengan metode lempeng agar dan metode membran. Kedua metode ini digunakan untuk membandingkan pelepasan obat dari sediaan semi solid yang bervariasi (Voight, 1994).

Berdasarkan hal-hal tersebut diatas, maka dalam penelitian ini akan diformulasikan natrium diklofenak dalam bentuk krim dengan menggunakan berbagai konsentersai zat peningkat penetrasi (enhancer) yaitu propilen glikol. Kemudian dilakukan evaluasi krim dan uji pelepasan zat berkhasiatnya.

\section{ALAT, BAHAN DAN METODE PENELITIAN}

\section{Alat}

Alat-alat yang digunakan dalam penelitian ini adalah peralatan yang biasa digunakan untuk formulasi krim, alat uji difusi franz, $\mathrm{pH}$ meter Metrohm, termometer, viskometer Brookfield DV-E.

\section{Bahan}

Bahan yang digunakan dalam penelitian ini adalah aquadestilata, cera alba, natrium tetraborat, parafin cair, propilen glikol dan natrium diklofenak.

\section{METODE}

\section{Penyiapan Bahan Baku dan Penyusunan Formulasi Krim Natrium Diklofenak}

Penyiapan bahan baku meliputi pemeriksaan natrium diklofenak dilakukan secara organoleptis meliputi pemerian serta kelarutannya serta dibandingkan dengan monografi natrium diklofenak yang ada (sesuai dengan British Pharmacopoeia dan Farmakope Indonesia Edisi IV).

\section{Formulasi Krim Natrium Diklofenak}

Formulasi sediaan krim natrium diklofenak dengan variasi konsentrasi propilen glikol sebagai enhancer menggunakan komposisi seperti terlihat pada Tabel 1. 
Tabel 1. Formula Krim natrium diklofenak dengan

\begin{tabular}{lcccc}
\multicolumn{5}{c}{ berbagai Konsentrasi Propilen Glikol } \\
\hline \multicolumn{1}{c}{ Komposisi } & \multicolumn{4}{c}{ Formula } \\
\cline { 2 - 5 } \multicolumn{1}{c}{ Krim } & $\mathrm{F}_{0}$ & $\mathrm{~F}_{1}$ & $\mathrm{~F}_{2}$ & $\mathrm{~F}_{3}$ \\
& $(\%)$ & $(\%)$ & $(\%)$ & $(\%)$ \\
\hline Natrium & 1 & 1 & 1 & 1 \\
Diklofenak & & & & \\
Parafin Cair & 50,0 & 50,0 & 50,0 & 50,0 \\
Cera Alba & 16,0 & 16,0 & 16,0 & 16,0 \\
Natrium & 0,8 & 0,8 & 0,8 & 0,8 \\
Tetraborat & & & & \\
Propilen Glikol & - & 3 & 5 & 7 \\
$\begin{array}{l}\text { Air Suling } \\
\text { sampai }\end{array}$ & 100 & 100 & 100 & 100 \\
\hline Keterangan & & & & \\
\hline
\end{tabular}

Keterangan:

Formulasi krim dengan konsentrasi propilen glikol berturut-turut sebesar 0\%, 3\%, 5\%, dan $7 \%$ untuk $F_{0}, F_{1}, F_{2}$, dan $F_{3}$.

\section{Pembuatan Krim Natrium Diklofenak}

Fasa minyak berupa cera alba dan parafin cair dipanaskan pada suhu sekitar $70{ }^{\circ} \mathrm{C}$ diatas penangas air. Natrium tetraborat dilarutkan dalam aquadest panas pada suhu sekitar $72{ }^{\circ} \mathrm{C}$ sebagai fasa air dan ditambahkan natrium diklofenak yang sudah dilarutkan dalam aquadest. Kemudian fasa air dicampurkan kedalam fasa minyak dalam mortir panas, dan diaduk sampai terbentuk massa krim yang baik dan homogen.

Sedangkan untuk formula yang mengandung propilen glikol, propilen glikol dicampurkan pada fasa airnya.

\section{Evaluasi Sediaan Krim Natrium Diklofenak}

Evaluasi sediaan krim dilakukan setiap minggu selama 56 hari penyimpanan, yang meliputi pemeriksaan:

\section{i) Pengamatan Organoleptis dan}

\section{Konsistensi Krim}

Pengamatan dilakukan dengan melihat perubahan-perubahan bentuk, warna, bau, dan konsistensi dari krim.

\section{ii) Pengamatan Perubahan Viskositas}

Pengukuran viskositas dilakukan dengan menggunakan viskometer Brookfield DVE.

\section{iii) Pengamatan Perubahan pH}

Pengukuran $\mathrm{pH}$ dilakukan dengan menggunakan $\mathrm{pH}$ meter Metrohm, yaitu dengan cara kedalam larutan krim.

\section{iv) Penentuan Sifat Aliran}

Sifat aliran ditentukan dengan mengukur viskositas pada spindle yang sama pada berbagai kecepatan putaran (RPM).

\section{Pengujian pelepasan natrium diklofenak sebagai zat berkhasiat secara in-vitro}

Pengujian pelepasan natrium diklofenak sebagai zat berkhasiat dilakukan dengan cara-cara sebagai berikut:

\section{A. Penyiapan membran Spangler}

Membran yang digunakan adalah kertas Whatman no.1 yang dibacam dengan cairan Spangler yang telah dimodifikasi. Komposisi cairan Spangler :

$\begin{array}{ll}\text { Asam palmitat } & 10 \% \\ \text { Asam Oleat } & 15 \% \\ \text { Asam stearat } & 5 \% \\ \text { Minyak Kelapa } & 15 \% \\ \text { Squalen } & 5 \% \\ \text { Parafin } & 10 \% \\ \text { Kolesterol } & 5 \% \\ \text { Lilin Putih } & 15 \%\end{array}$

\section{Cara pembuatan membran:}

Semua bahan untuk cairan Spangler dicampurkan dan dilumerkan diatas penangas air sampai suhu $80^{\circ} \mathrm{C}$, dan diaduk sampai homogen. Kedalamnya dimasukkan kertas Whatman no.1 dibiarkan selama 15 
menit. Kertas diangkat dan dikeringkan dengan cara meletakkan membran diatas kertas saring dengan tujuan untuk mempercepat pengeringan.

\section{B. Pembuatan dapar fosfat $\mathrm{pH} 7,4$}

Sebanyak $50 \quad \mathrm{ml}$ larutan Kalium monofosfat 0,2 M dimasukkan kedalam labu ukur $200 \mathrm{ml}$, kemudian ditambahkan kira-kira 39,1 ml larutan $\mathrm{NaOH} \mathrm{0,2} \mathrm{M}$ dan dilakukan pengujian $\mathrm{pH}$ menggunakan $\mathrm{pH}$ meter hingga $\mathrm{pH}=7,4$. Selanjutnya ditambahkan air sampai tanda batas, kemudian labu ukur dikocok dan disimpan dalam wadah tertutup rapat, dibungkus dengan alumunium foil.

\section{Penentuan panjang gelombang maksimum}

Penentuan panjang gelombang maksimum dilakukan dengan membuat larutan baku natrium diklofenak dalam dapar fosfat $\mathrm{pH}$ 7,4 dengan konsentrasi $10 \mathrm{ppm}$ dan dicari panjang gelombang maksimum untuk larutan baku natrium diklofenak tersebut.

\section{Pembuatan kurva baku natrium diklofenak pada panjang gelombang maksimum}

Pembuatan kurva baku natrium diklofenak pada panjang gelombang maksimum dilakukan dengan cara:

1) Dibuat 7 konsentrasi natrium diklofenak dalam dapar fosfat $\mathrm{pH} 7,4$ (5 ppm; 7,5 ppm; $10 \mathrm{ppm} ; 12,5 \mathrm{ppm}$; 15 ppm; 17,5 ppm).

2) Diukur absorbansinya pada panjang gelombang maksimum.

3) Dibuat grafik kurva baku natrium diklofenak.

\section{E. Penetapan Kadar Natrium Diklofenak}

Uji permeasi perkutan dilakukan dengan menggunakan metode flow through yang terdiri dari sel difusi Franz, pompa peristaltik, batang pengaduk, gelas kimia, penangas air, penampung reseptor, termometer, dan selang dengan diameter 5 mm. Sampel krim uji ditimbang 1,0 g dan diratakan diatas membran. Suhu media adalah $37 \pm 0,5{ }^{\circ} \mathrm{C}$ dengan total volume cairan reseptor $100 \mathrm{~mL}$. Pompa peristaltik menghisap cairan reseptor dari gelas kimia kemudian dipompa ke sel sehingga terjadi aliran hidrodinamis. Proses dilakukan selama 5 jam. Cuplikan diambil dari media permeasi pada menit ke $5,10,15,30,45,60,75,90,105$ dan 120. Kadar natrium diklofenak yang terdifusi melalui membran ke media permeasi kemudian ditetapkan dengan cara spekrofotometri UV pada $\lambda=276 \mathrm{~nm}$.

\section{F. Pengujian Iritasi Krim Natrium Diklofenak}

Pengujian iritasi krim dilakukan terhadap 10 orang sukarelawan.

\section{G. Analisis Data}

Profil uji difusi dibuat dalam grafik dan analisis data dilakukan secara statistik

\section{HASIL DAN PEMBAHASAN}

\section{Hasil Penyiapan Bahan Baku}

Penyiapan bahan baku meliputi pemeriksaan secara organoleptis yaitu pemerian dan kelarutan baik natrium diklofenak maupun propilen glikol

Tabel 2. Hasil Pemeriksaan Pemerian dan Kelarutan Natrium Diklofenak

\begin{tabular}{cc}
\hline Pemeriksaan & Hasil Pengamatan \\
\hline Pemerian : & Serbuk \\
Bentuk & Putih \\
Warna & Tidak Berbau \\
Bau & Larut air dan etanol \\
Kelarutan : &
\end{tabular}


Tabel3. Hasil Pemeriksaan Pemerian dan Kelarutan Propilen Glikol

\begin{tabular}{lc}
\hline \multicolumn{1}{c}{ Pemeriksaan } & Hasil Pengamatan \\
\hline Pemerian : & \\
Bentuk & Cairan Kental \\
$\quad$ Warna & Jernih, tidak bewarna \\
Kelarutan dalam : & Tidak berbau \\
Air & \\
Aseton & Larut \\
Kloroform & Larut \\
\hline
\end{tabular}

Dari Tabel 2 dan Tabel 3 dapat diketahui bahwa natrium diklofenak dan propilen glikol yang digunakan dalam penelitian mempunyai pemerian dan kelarutan yang sama dengan yang terdapat dalam pustaka.

\section{Hasil Uji Kestabilan Fisik Krim Natrium Diklofenak}

\section{Hasil Pengamatan Organoleptis}

Hasil Pengamatan organoleptis meliputi konsistensi, warna dan bau.

Data hasil pengamatan organoleptis selama 56 hari penyimpanan menunjukkan bahwa sediaan krim natrium diklofenak dengan variasi konsentrasi propilen glikol $(0,3,5$, dan $7 \%$ ) merupakan sediaan yang stabil, karena tidak mengalami perubahan warna, bau, tekstur, dan konsistensinya.

Tabel 4. HasilPengamatan Perubahan Organoleptis Krim Natrium Diklofenak dengan berbagai Konsentrasi Propilen Glikol

\begin{tabular}{ccccc}
\hline \multirow{2}{*}{ Hari ke- } & \multicolumn{5}{c}{ Formula } \\
\cline { 2 - 5 } & F0 & F1 & F2 & F3 \\
\hline 1 & - & - & - & - \\
7 & - & - & - & - \\
14 & - & - & - & - \\
21 & - & - & - & - \\
28 & - & - & - & - \\
35 & - & - & - & - \\
42 & - & - & - & - \\
49 & - & - & - & - \\
56 & - & - & - & - \\
\hline
\end{tabular}

Keterangan:
Krim natrium diklofenak $1 \%$ dengan propilen glikol berturut-turut sebesar 0\%, 3\%, 5\%, dan 7\% untuk $F_{0}, F_{1}, F_{2}$, dan $F_{3}$.

$(-) \quad$ : Tidak terjadi perubahan

(+) : Terjadi Perubahan

\section{Hasil Pengamatan Perubahan Viskositas}

Hasil pengukuran viskositas krim natrium diklofenak dengan berbagai konsentrasi propilen glikol selama 56 hari penyimpanan, dapat dilihat dalam Gambar 1.

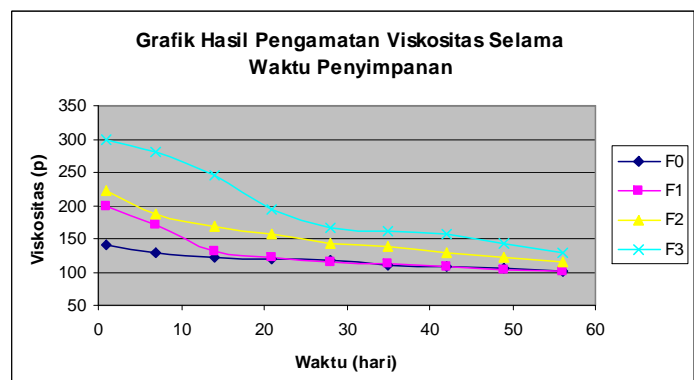

Gambar 1. Grafik Hasil Pengamatan Perubahan Viskositas Krim Natrium Diklofenak dengan Enhancer Propilen Glikol selama Waktu Penyimpanan

Keterangan :

Krim natrium diklofenak $1 \%$ dengan propilen glikol berturut-turut sebesar 0\%, 3\%, 5\%, dan 7\% untuk $F_{0}, F_{1}, F_{2}$, dan $F_{3}$.

Dari Gambar 1 juga diketahui bahwa semua formula krim natrium diklofenak dengan berbagai konsentrasi propilen glikol mengalami penurunan viskositas selama 56 hari penyimpanan. Penurunan viskositas pada krim yang mengandung propilen glikol $7 \%$ lebih tinggi dibandingkan dengan yang mengandung propilen glikol 0, 3 dan 5\%. Penurunan ini mungkit disebabkan oleh penambahan jumlah propilen glikol yang lebih tinggi dibandingkan oleh formula lainnya. 


\section{Hasil Pengamatan Perubahan pH}

Hasil pengamatan perubahan $\mathrm{pH}$ krim natrium diklofenak dengan berbagai konsentrasi propilen glikol selama 56 hari penyimpanan berada pada kisaran antara 7,19 dan 7,48 yang dapat dilihat dalam Gambar 2.

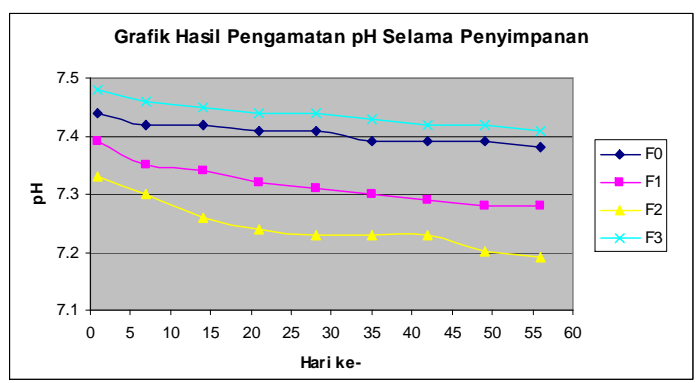

Gambar 2. Grafik Hasil Pengamatan Perubahan pH Krim Natrium Diklofenak dengan Enhancer Propilen Glikol selama Waktu Penyimpanan

Keterangan :

Krim natrium diklofenak $1 \%$ dengan propilen glikol berturut-turut sebesar 0\%, 3\%, 5\%, dan 7\% untuk $F_{0}, F_{1}, F_{2}$, dan $F_{3}$.

Gambar 2 menunjukkan bahwa $\mathrm{pH}$ semua formula krim natrium diklofenak yang mengandung propilen glikol 5\% lebih rendah dibandingkan dengan yang mengandung propilen glikol 0, 3 dan $7 \%$. Semua sediaan krim natrium diklofenak mengalami penurunan $\mathrm{pH}$ setelah 56 hari pengamatan. Walaupun mengalami penurunan $\mathrm{pH}$, tetapi $\mathrm{pH}$ formula krim natrium diklofenak dengan berbagai konsentrasi propilen glikol, masih memenuhi persyaratan $\mathrm{pH}$ suatu sediaan topikal, yaitu antara 5,5 - 10 (Harry, 1973).

\section{Hasil Penentuan Sifat Aliran}

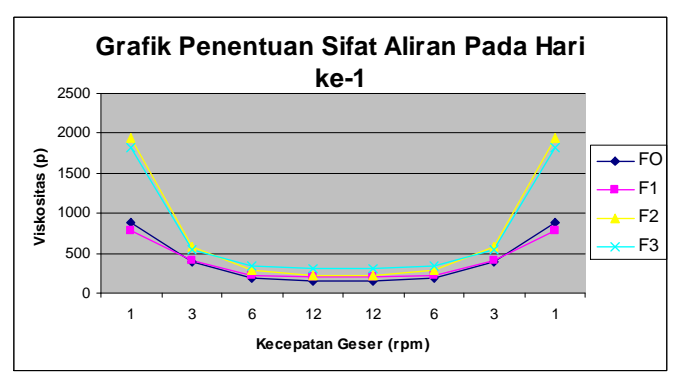

Gambar 3. Grafik Penentuan Sifat Aliran Krim Natrium Diklofenak Hari ke-1

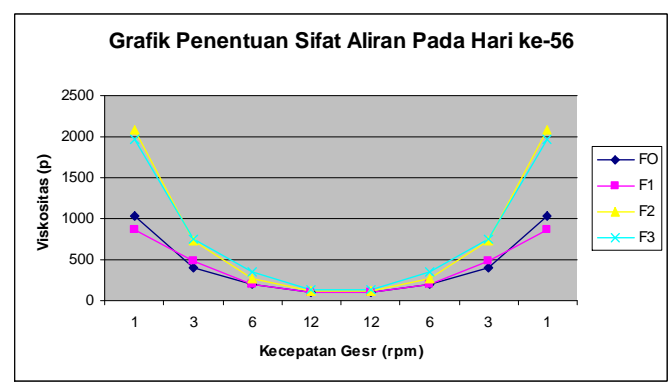

Gambar 4. Grafik Hasil Penentuan Sifat Aliran Krim Natrium Diklofenak Hari ke-56

\section{Keterangan :}

Krim natrium diklofenak $1 \%$ dengan propilen glikol berturut-turut sebesar 0\%, 3\%, 5\%, dan 7\% untuk $F_{0}, F_{1}, F_{2}$, dan $F_{3}$.

Dari data pada Tabel 4 dapat disimpulkan sifat aliran semua formula krim natrium diklofenak pada hari ke-1 dan ke-56 tidak mengalami perubahan yaitu bersifat pseudoplastik.

\section{Hasil Pengujian pelepasan natrium diklofenak sebagai zat berkhasiat secara invitro}

\section{Hasil penentuan panjang gelombang maksimum}

Gambar 5 berikut menunjukkan hasil pengukuran panjang gelombang maksimum larutan Natriumdiklofenak dengan konsentrasi 10 ppm 


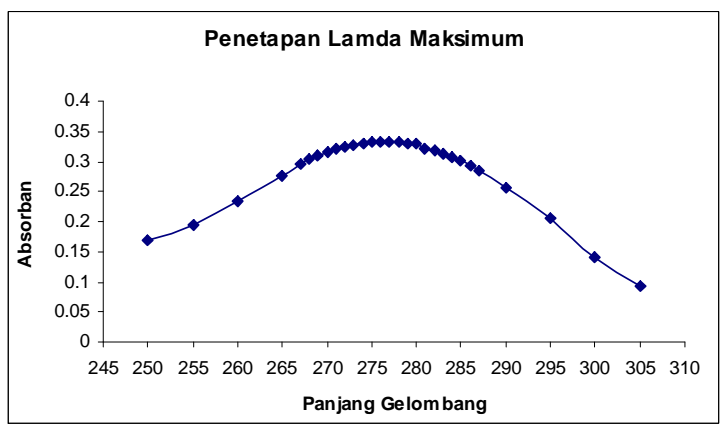

Gambar 5. Grafik Panjang Gelombang Maksimum Larutan Natrium Diklofenak 10 ppm dalam Dapar Fosfat pH 7,4

Dari Gambar 5 dapat diketahui bahwa panjang gelombang maksimum natrium diklofenak berada pada $276 \mathrm{~nm}$. Dengan demikian pembuatan kurva baku dilakukan pada panjang gelombang $276(\lambda=276 \mathrm{~nm})$.

\section{Hasil pembuatan kurva baku natrium diklofenak pada panjang gelombang maksimum}

Hasil pembuatan kurva baku natrium diklofenak pada panjang gelombang maksimum dapat dilihat dalam Tabel 5 dan Gambar 6.

Tabel 5. Hasil Serapan Larutan Natrium Diklofenak dalam Dapar fosfat pH 7,4 pada $\lambda=276 \mathrm{~nm}$

\begin{tabular}{cccc}
\hline \multirow{2}{*}{$\begin{array}{c}\text { Konsentrasi } \\
(\mathrm{ppm})\end{array}$} & \multicolumn{3}{c}{ Absorban (A) } \\
\cline { 2 - 4 } & A 1 & A 2 & A rata-rata \\
\hline 5 & 0.1745 & 0.1749 & 0.1747 \\
7.5 & 0.2438 & 0.2436 & 0.2437 \\
10 & 0.3232 & 0.3232 & 0.3232 \\
12.5 & 0.4052 & 0.407 & 0.4061 \\
15 & 0.4777 & 0.4785 & 0.4781 \\
17.5 & 0.5693 & 0.5695 & 0.5694 \\
\hline
\end{tabular}

Dari hasil pengukuran serapan larutan natrium diklofenak berbagai konsentrasi dalam larutan dapar fosfat $\mathrm{pH} 7,4$ dapat dibuat grafik hubungan serapan terhadap konsentrasi yang berbentuk garis lurus. Hal ini menunjukkan bahwa dengan naiknya konsentrasi, maka besarnya serapannya juga akan naik dengan persamaan regresi linear: $\mathrm{Y}=0,0315 \mathrm{x}+0,0111$ dengan $\mathrm{R}^{2}=$ 0,9987 .

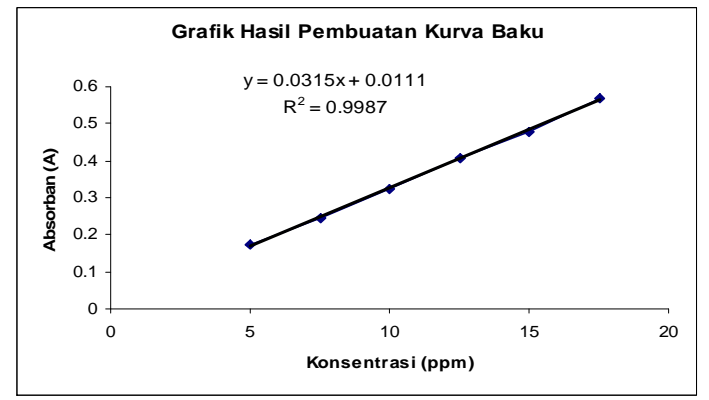

Gambar 6. Grafik Hasil Pembuatan Kurva Baku Natrium Diklofenak dalam Larutan Dapar Fosfat pH 7,4

\section{Hasil Uji Penetapan Kadar Natrium Diklofenak}

Hasil pengukuran konsentrasi natrium diklofenak melalui membran spangler dapat dilihat pada Gambar 7.

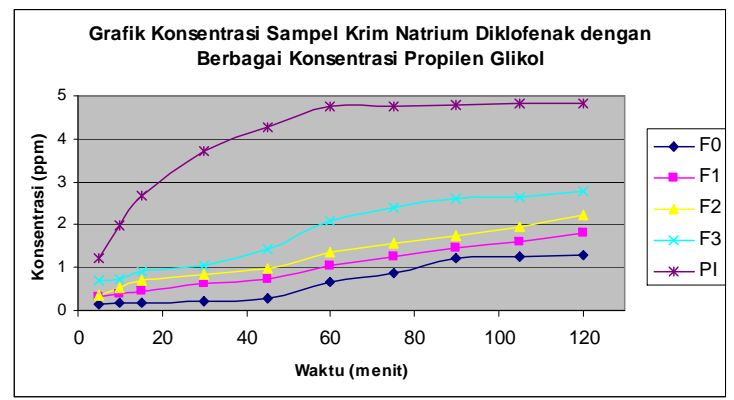

Gambar 7. Grafik Konsentrasi Sampel Krim Natrium Diklofenak dengan Berbagai Konsentrasi Propilen Glikol

Keterangan:

Krim natrium diklofenak $1 \%$ dengan propilen glikol berturut-turut sebesar 0\%, 3\%, 5\%, dan 7\% untuk $F_{0}, F_{1}, F_{2}$, dan $F_{3}$.

$P I$ : Gel natrium diklofenak $1 \%$

Dari Gambar 7 tampak bahwa prudok inovator mempunyai laju permeasi yang paling tinggi yaitu dengan laju permeasi $\mathrm{dC} / \mathrm{dt}=0,0282 \mathrm{ppm} /$ menit sedangkan untuk formula krim dengan penambahan propilen glikol 3\% $\left(\mathrm{F}_{1}\right)$ mempunyai laju permeasi $\mathrm{dC} / \mathrm{dt}=0,0132 \mathrm{ppm} /$ menit, 
formula krim dengan penambahan propilen glikol $5 \%\left(\mathrm{~F}_{2}\right)$ mempunyai laju permeasi $\mathrm{dC} / \mathrm{dt}=0,0155 \mathrm{ppm} /$ menit, formula $\mathrm{krim}$ dengan penambahan propilen glikol $7 \%$ $\left(\mathrm{F}_{3}\right)$ mempunyai laju permeasi $\mathrm{dC} / \mathrm{dt}=$ $0,0203 \mathrm{ppm} / \mathrm{menit}$, yang semuanya jelas lebih tinggi jika dibandingkan dengan formula krim tanpa penambahan propilen glikol $\left(\mathrm{F}_{0}\right)$ dengan laju permeasi $\mathrm{dC} / \mathrm{dt}=$. $0,0116 \mathrm{ppm} / \mathrm{menit}$. Dengan demikian, jika dibandingkan dengan laju permeasi formula standar, laju permeasi krim natrium diklofenak dengan penambahan propilen glikol lebih cepat melepaskan zat aktif dibanding dengan formula standar. Propilen glikol juga dapat meningkatkan penetrasi natrium diklofenak ke dalam kulit manusia. Namun bila dibandingkan dengan produk inovator laju difusinya jelas berbeda karena dari basisnya pun sudah berbeda.

\section{Hasil Uji Iritasi Krim Natrium Diklofenak}

Hasil uji keamanan krim natrium diklofenak melalui pengamatan terjadinya reaksi iritasi atau tidak pada punggung tangan sukarelawan, dapat dilihat pada Tabel 6.

Data pada Tabel 6 menunjukkan bahwa formula krim dengan dan tanpa propilen glikol tidak menyebabkan adanya iritasi yang berupa kemerahan, pembengkakan ataupun luka pada punggung tangan sukarelawan. Dengan melihat hasil uji keamanan sediaan krim natrium diklofenak dengan konsentrasi propilen glikol tertinggi tidak menimbulkan iritasi, maka dapat diartikan bahwa sediaan krim natrium diklofenak dengan konsentrasi propilen glikol yang lebih rendah pun akan aman untuk digunakan. Jadi, sediaan krim natrium diklofenak dengan konsentrasi propilen glikol 3, 5, dan 7\% aman untuk digunakan.

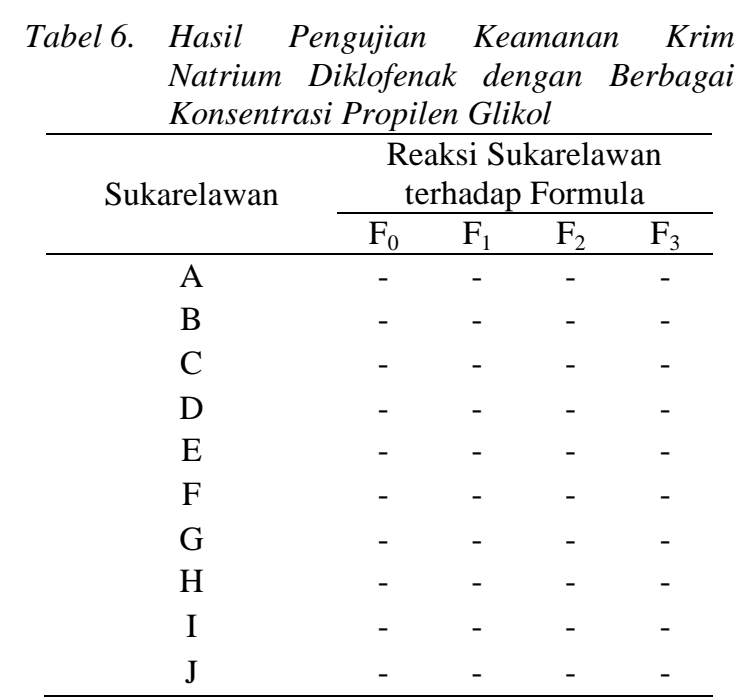

\section{Keterangan :}

Krim natrium diklofenak $1 \%$ dengan propilen glikol berturut-turut sebesar $0 \%, 3 \%, 5 \%$, dan $7 \%$ untuk $F_{0}, F_{1}, F_{2}$, dan $F_{3}$.

(-) : Tidak terjadi Iritasi

\section{KESIMPULAN DAN SARAN}

\section{Kesimpulan}

Dari hasil penelitian mengenai pengaruh propilen glikol terhadap laju difusi krim natrium diklofenak dengan basis hidrofobik secara invitro dapat diambil beberapa kesimpulan yaitu:

1.Profil pelepasan zat natrium diklofenak dapat dilihat dari laju difusi, untuk formula yang tidak mengandung natrium diklofenak memiliki laju difusi 0,0116 $\mathrm{ppm} / \mathrm{menit}$ sedangkan untuk formula yang mengandung propilen glikol 3, 5 dan $7 \%$ masing-masing memiliki laju difusi 0,$0132 ; 0,0155$ dan 0,0203 $\mathrm{ppm} / \mathrm{menit}$.

2.Penambahan propilen glikol dapat meningkatkan laju difusi krim natrium diklofenak secara invitro dibandingkan dengan krim natrium diklofenak tanpa penambahan propilen glikol.

3.Ditinjau dari evaluasi stabilitas krim yang terdiri dari pemeriksaan organoleptis, $\mathrm{pH}$, viskositas, dan konsistensi selama 56 hari penyimpanan diambil kesimpulan bahwa 
formulasi sediaan krim natrium diklofenak dengan penambahan propilen glikol stabil dan tidak menimbulkan iritasi pada kulit sehingga aman untuk digunakan.

\section{Saran}

Dari hasil penelitian dapat disarankan:

1.Perlu dilakukan penelitian uji difusi natrium diklofenak dengan basis yang bebeda seperti basis hidrofilik.

2.Perlu dilakukan penelitian uji difusi natrium diklofenak menggunakan membran yang lebih lain seperti membran alami yaitu membran kulit tikus dan membran kulit ular.

3.Perlu dilakukan penelitian uji invivo terhadap krim natrium diklofenak untuk melihat korelasi antara penelitian invivo dengan invitro.

\section{UCAPAN TERIMA KASIH}

Penulis mengucapkan terima kasih kepada Prof. Dr. Anas Subarnas, M.Sc.

\section{DAFTAR PUSTAKA}

1. Agoes, G. 1986, Penelitian Difusi Asam Salisilat dan Kloramfenikol dari Sediaan Semisoloda dengan Pembawa Vaselin, Campuran Vaselin Propilenglikol dan Vaselin Lemak Bulu Domba secara In vitro. Acta Pharmaceutica IX(3); Bandung. ITB.

2. Agoes, G.; Darijanto, S.T. 1993, Teknologi Farmasi Likuida Dan Semi Solida. Pusat Antar Universitas Bidang Ilmu Hayati ITB; Bandung.

3. Harry, R. G. 1973, Harry's Cosmeticology $6^{\text {th }}$ Edition. Leonard Hill Books an Intertext Publisher. London, p.2-3, 38-93.

4. Lachman, Leon. 1994, Teori dan Praktek Farmasi Industri II (Penerjemah: Siti Suyatmi). Penerbit: UI-Press; Jakarta.

5. Shargel, Andrew. 1988, Biofarmasetika Dan Farmakokinetika Terapan. Edisi Kedua. Penerbit: Airlangga University-Press; Surabaya

6. Syarif, Amir; dkk. 1998, Farmakologi dan Terapi, Edisi 4. Gaya Baru; Jakarta

7. Voigth, R. 1994, Buku Pelajaran Teknologi Farmasi, Edisi Kelima. Penerjemah: Soendari Noerono S, Gajah mada University-Press; Yogyakarta.

8. Weller, P.J.; \& Rowe, R.C. 1994, Handbook of Pharmaceutical Excipients. Fourth Edition; London: The Pharmaceutical Press 